\title{
Evaluating the Effect of Floating Photovoltaic on Trophic State using Mesocosm Experiments
}

\author{
Syarfina Andini' ${ }^{1}$, Nyoman Suwartha ${ }^{1 *}$, Eko Adhi Setiawan², Samsul Ma'arif ${ }^{2}$ \\ ${ }^{1}$ Department of Civil Engineering, Faculty of Engineering, Universitas Indonesia, Kampus UI Depok, \\ Depok 16424, Indonesia
}

${ }^{2}$ Department of Electrical Engineering, Faculty of Engineering, Universitas Indonesia, Kampus UI Depok, Depok 16424, Indonesia

\begin{abstract}
.
The applications of floating photovoltaic (FPV) on water bodies are currently on a global demand. Despite the increasing popularity of floating photovoltaic industry, studies on ecological effects of lake coverage using floating photovoltaic - especially in tropical countries - haven't been widely conducted. This study evaluates the effect of floating photovoltaic on dissolved oxygen and trophic state changes in water bodies using mesocosm experiment. Trophic state is an indicator of the degree of transformation and ecological disruption in water bodies. The parameters used to assess trophic index (Trophic State Index, TSI) are total phosphorus, chlorophyll-a, and water transparency. TSI uses mathematical equations to calculate data of the experiments, so that the expression of trophic level can be determined. The mesocosm experiment was conducted from March $25^{\text {th }}$ to April $15^{\text {th }} 2021$ in Mahoni Lake, in which a total amount of 7 water samples were collected from each mesocosms. Our results show that mesocosms with 100\% FPV cover have a lower dissolved oxygen ( $p$-value < 0,05$)$ and a lower TSI value ( $\mathrm{p}$-value $<0,05$ ) compared to mesocosms without FPV cover (control). According to the TSI value, despite the decrease in TSI value, the trophic state was still classified as eutrophic. The results obtained are an important tool for further studies focusing on water quality and ecology impact regarding FPV on water bodies.
\end{abstract}

Keywords: Floating photovoltaic, trophic state, dissolved oxygen, mesocosm

\section{Introduction}

The high demand of renewable energy and the pressure to reduce greenhouse gases have increased solar-powered projects all over the world. Indonesian government, through Ministry of Energy and Mineral Resources, has targeted to develop the initiative of solar power usage in Indonesia amounts to $6.5 \mathrm{GW}$ in 2025 . The most common application for solar energy usage is solar panel systems (photovoltaic, PV). 
Photovoltaic module is one the most effective, sustainable, and environmentally friendly systems in the renewable energy field. Applications of floating photovoltaic (FPV) on water bodies are currently in higher demand due to the availability of water bodies in various countries, thus reducing the cost of land purchase and the cost for power plants operation (Sahu et al., 2016). Floating photovoltaic has also been proven to have several benefits, such as reducing vaporization in water bodies or reservoirs (Santafé et al., 2014) and increasing water quality by limiting algae growth by covering the water's surface (Chang et al., 2014). A number of researches have developed mathematical models to observe the effect of cover's surface area to ecological effect in reservoirs (Haas et al., 2020; Santafé et al., 2014) or fish ponds (Château et al., 2019) in subtropical countries. Despite the increasing popularity of floating photovoltaic industry, studies on ecological effects of lake coverage using floating photovoltaic especially in tropical countries - haven't been widely conducted.

Here, we propose to discuss these effects using a case study from Indonesia. In this research, we present an experimental study regarding the effect of floating solar panel cover on changes of dissolved oxygen and trophic state. Trophic state is an indicator of the degree of transformation and ecological disruption in water bodies. Trophic State Index (TSI) is a classification system to determine trophic state based on total phosphorus, chlorophyll-a, and water transparency (Skwierawski, 2013). TSI uses mathematical equations to calculate the data of the experiments, which allows us to give the expression of trophic level (Carlson, 1997). Table 1 shows the TSI value and the classification of water bodies (Bekteshi \& Cupi, 2014; Carlson, 1997; Prasad \& Siddaraju, 2012).

This study was conducted using mesocosm experiments. Many studies use these controlled environments to examine ecosystem responses to factors such as nutrient addition (Escaravage et al., 1995; Tonetta et al., 2018; Zingel et al., 2018); light limitation (Escaravage et al., 1995; Gillette et al., 2014; Winder et al., 2012); and climate change (Landkildehus et al., 2014; Sommer et al., 2007; Stewart et al., 2013). The use of in situ mesocosms to study the effects of floating photovoltaic cover as a way to evaluate and assess the ecological processes under closed system. We believe that closer interactions between bench and field studies would be beneficial by contributing to a better scientific understanding of the effect of floating photovoltaic in a specific way (Machado et al., 2019).

The research objective described in this study is to analyze the issue regarding the effect of floating photovoltaic on dissolved oxygen and trophic state changes using mesocosm experiments. This research can add new insights regarding the effect of floating photovoltaic on water quality and their impact on the ecosystem and every piece of information obtained in this work becomes a useful consideration for the energy sector and ecology that are looking to develop an effective design concept for the deployment of floating solar modules in water bodies. 
Table 1: The trophic state index values and classification

\begin{tabular}{|c|c|c|}
\hline TSI Value & Trophic State & Attributes \\
\hline$<30$ & Oligotrophic & Clear water, oxygen throughout the year in the hypolimnion \\
\hline $30-40$ & Oligotrophic & Hypolimnia of shallower lakes may become anoxic \\
\hline $40-50$ & Mesotrophic & $\begin{array}{l}\text { Water moderately clear, increasing probability of anoxia during } \\
\text { summer }\end{array}$ \\
\hline $50-60$ & Eutrophic & Decreased transparency, warm-water fisheries only \\
\hline $60-70$ & Eutrophic & $\begin{array}{l}\text { Dominance of blue-green algae, algal scum, andmacrophyte } \\
\text { problems }\end{array}$ \\
\hline $70-80$ & Eutrophic & $\begin{array}{l}\text { Light limited productivity, heavy algal blooms throughout the } \\
\text { summer }\end{array}$ \\
\hline$>80$ & Eutrophic & Algal scum, summer fish kills, few macrophytes \\
\hline
\end{tabular}

Sources: Bekteshi \& Cupi, 2014; Carlson, 1997; Prasad \& Siddaraju, 2012.

\section{Materials and methods}

\subsection{Experimental Design}

The mesocosm experiment was conducted in artificial Mahoni Lake $\left(6^{\circ} 21^{\prime} 48.8304^{\prime \prime}\right.$ S; 106 ${ }^{\circ} 9^{\prime} 31.3824^{\prime \prime}$ E) in Universitas Indonesia, Depok City. Mahoni Lake was built in 1996 with surface area of 52,996 $\mathrm{m}^{2}$ and average depth of $1.5 \mathrm{~m}$. This lake has the first bifacial floating photovoltaic in Indonesia. The aforementioned floating photovoltaic has 36 bifacial solar panels that are able to generate 10,000-13,000 Watt.

Mesocosms consisted of transparent polyethylene containers with internal dimensions of $50 \times 50 \mathrm{~cm}, \pm 1 \mathrm{~m}$ in depth, and $\pm 200 \mathrm{~mL}$ in volume. The bottom part of the mesocosms was closed, but their surface was opened to enable gas exchange between water and atmosphere (Tonetta et al., 2018). They were then deployed in the pelagic area of the lake (whose depth was $\pm 1 \mathrm{~m}$ ) and were filled with upper mixed layer water from the lake with no sediment within the mesocosms. Mesocosms were attached to floating photovoltaic with treatments as follows: 1) placed under floating photovoltaic with $100 \%$ sunlight cover (P) and 2) placed outside floating photovoltaic without cover as control (NP) (Figure 1). Each treatment of the mesocosms was replicated twice, amounting to four mesocosms in total. Physical-chemical-biological measurements started on the next day (day 1) and was conducted until day 22.

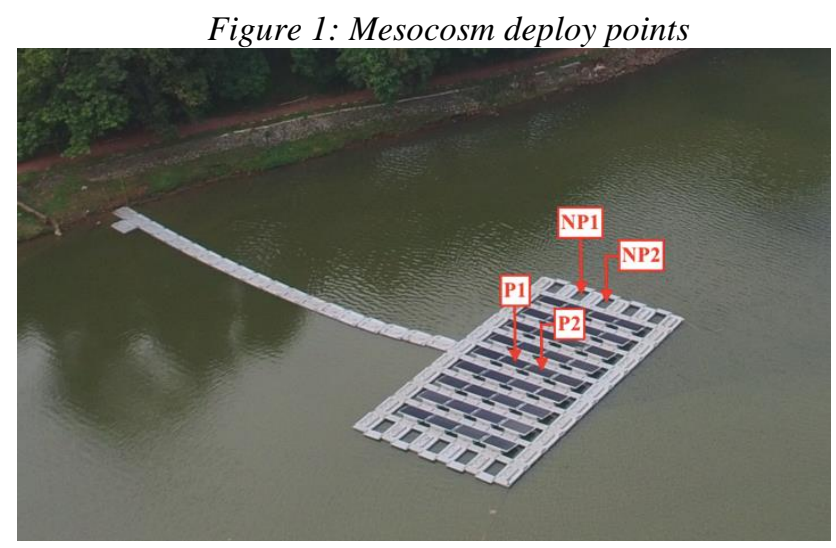


The study was conducted from March $25^{\text {th }}$ to April $15^{\text {th }} 2021$. A total amount of 7 water samples were collected from each of the four mesocosms, collected from $30-\mathrm{cm}$ depth of each mesocosm between 10:00 and 12:00 h. Dissolved oxygen concentrations $\left(\mathrm{O}_{2}\right)$ were obtained using DO Meter Lutron PDO-519. Five hundred milliliter samples were collected from each mesocosm to analyze two parameters: total phosphorus and chlorophyll-a. Chlorophyll-a (Chl-a) was determined by extraction using DMSO and acetone $90 \%$ method, and was measured by spectrophotometer (Qiu et al., 2017). Total phosphorus was determined by using the amino acid method (adapted from Standard Methods for the Examination of Water and Wastewater). Water transparency was measured using a standard black and white Secchi disc with a $20-\mathrm{cm}$ diameter. The maximum depth where the disc can be seen when lowered into the water was marked and measured.

\subsection{Data Analysis}

TSI values were determined based on total phosphorus (TP), chlorophyll-a concentrations (Chl-a), and Secchi disc visibility (SD) using the following formulas (Carlson, 1997; Nürnberg, 1996; Skwierawski, 2013).

$$
\begin{array}{ll}
\text { TSI for total phosphorus }\left(\mathrm{TSI}_{\mathrm{TP}}\right) & =14.42 \ln (\mathrm{TP})+4.15 \\
\text { TSI for chlorophyll-a }\left(\mathrm{TSI}_{\mathrm{Chl}-\mathrm{a}}\right) & =9.81 \ln (\mathrm{Chl}-\mathrm{a})+30.6 \\
\text { TSI for Secchi disc }\left(\mathrm{TSI}_{\mathrm{SD}}\right) & =60-14.41 \ln (\mathrm{SD}) \\
\text { Trophic state index }(\mathrm{TSI}) & =\left(\mathrm{TSI}_{\mathrm{TP}}+\mathrm{TSI}_{\mathrm{Chl}-\mathrm{a}}+\mathrm{TSI}_{\mathrm{SD}}\right) / 3
\end{array}
$$

Total phosphorus and chlorophyll-a concentration in micrograms per liter, Secchi disc visibility in meter. TSI values in water bodies are then classified as oligotrophic (low productive), mesotrophic (moderately productive), and eutrophic (highly productive) (Prasad \& Siddaraju, 2012). The statistical difference analysis of all the parameters between mesocosms with $100 \%$ floating photovoltaic cover (P) and mesocosms without floating photovoltaic cover as control (NP) can be determined using a twosample t-Test. Statistical analysis was conducted using Microsoft Excel Version 16.43.

\section{Results and discussion}

\subsection{Influence of FPV-cover on DO-concentration}

Dissolved oxygen concentration of mesocosms without FPV cover (as NP) and mesocosms with 100\% FPV cover (as P) at day-1 and day-22 are presented in Table 2. At day-1, the initial dissolved oxygen concentrations of mesocosms without FPV cover were 4 and $3.9 \mathrm{mg} / \mathrm{L}$, while the final concentrations at day- 22 were 5 and $5.5 \mathrm{mg} / \mathrm{L}$. The minimum measured dissolved oxygen in mesocosms without FPV cover is 3.6 $\mathrm{mg} / \mathrm{L}$ and the largest is $5.5 \mathrm{mg} / \mathrm{L}$, the average dissolved oxygen is $4.14 \mathrm{mg} / \mathrm{L}$. In mesocosms with 100\% FPV cover, the initial dissolved oxygen concentrations at day1 were 3.5 and $3.7 \mathrm{mg} / \mathrm{L}$, while the final concentrations at day-22 were around 4.3 and $4.1 \mathrm{mg} / \mathrm{L}$. The minimum measured dissolved oxygen in mesocosms with $100 \% \mathrm{FPV}$ cover is $3.4 \mathrm{mg} / \mathrm{L}$ and the largest is $4.3 \mathrm{mg} / \mathrm{L}$, the average dissolved oxygen is 3.74 


\section{$7^{\text {th }}$ International Conference On}

\section{Modern Approaches in SCIENCE,}

TECHNOLOGY \& ENGINEERING

\section{8-20 June, 2021}

Brussels, Belgium

$\mathrm{mg} / \mathrm{L}$. The mesocosms without FPV cover showed a significant increase of dissolved oxygen concentration.

Table 2: The results of dissolved oxygen in four mesocosms at day-1 and day-22

\begin{tabular}{ccc}
\hline Date & $\begin{array}{c}\text { Sample } \\
\text { point* }\end{array}$ & $\begin{array}{c}\text { DO } \\
(\mathrm{mg} / \mathrm{L})\end{array}$ \\
\hline & NP1 & 4 \\
$25 / 03$ & NP2 & 3.9 \\
(Day-1) & P1 & 3.5 \\
& P2 & 3.7 \\
\hline & NP1 & 5 \\
$15 / 04$ & NP2 & 5.5 \\
(Day-22) & P1 & 4.3 \\
& P2 & 4.1 \\
\hline
\end{tabular}

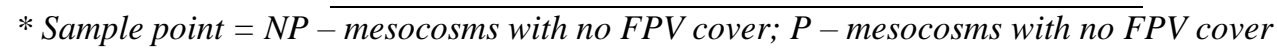

As seen from the graphic of the dissolved oxygen concentration of the four mesocosms shown in Figure 2, the trend of dissolved oxygen concentration in mesocosms without FPV significantly increased $(p$-value $<0.05)$ during the experiment compared to mesocosms with $100 \%$ FPV cover. Covering light would evidently influence the changes in dissolved oxygen ( $\mathrm{Li}$ at al., 2011). During the daytime, dissolved oxygen was affected by algae photosynthesis (Château et al., 2019; Yeh et al., 2014), hence, dissolved oxygen in mesocosms without FPV cover had a higher value than mesocosms with $100 \%$ FPV cover.

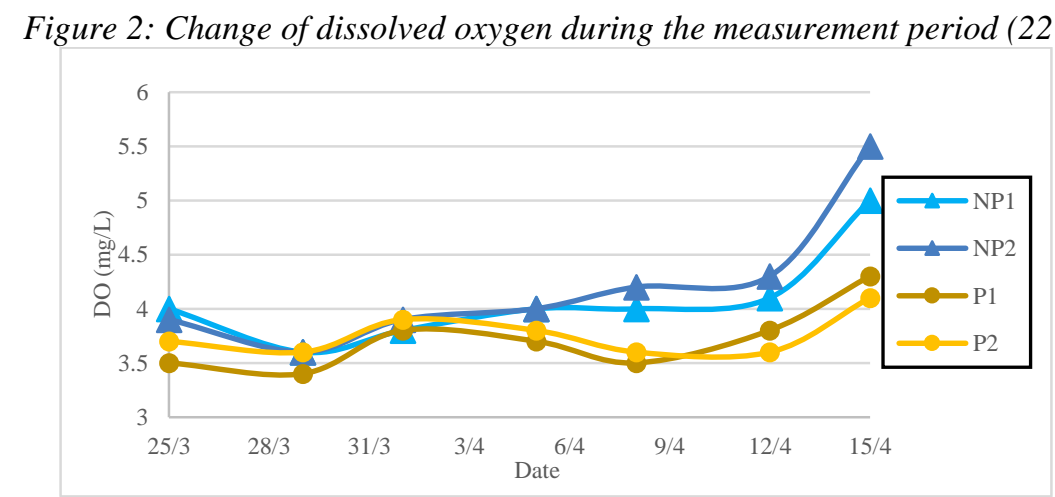

\subsection{Influence of FPV-cover on trophic state}

Total phosphorus, chlorophyll-a content, measured Secchi disc visibility, and TSI value of mesocosms without FPV cover (as NP) and mesocosms with 100\% FPV cover (as P) at day-1 and day-22 are presented in Table 3.

Table 3: The results of trophic state assessment in four mesocosms at day-1 and day-22

\begin{tabular}{ccccccc}
\hline Date & $\begin{array}{c}\text { Sample } \\
\text { point* }\end{array}$ & $\begin{array}{c}\text { SD } \\
(\mathrm{m})\end{array}$ & $\begin{array}{c}\text { TP } \\
(\mathrm{mg} / \mathrm{L})\end{array}$ & $\begin{array}{c}\text { Chl-a } \\
(\mathrm{mg} / \mathrm{L})\end{array}$ & $\begin{array}{c}\text { TSI } \\
\text { value }\end{array}$ & State** $^{* *}$ \\
\hline \multirow{2}{*}{$25 / 03$} & NP1 & 0.192 & 3.94 & 0.5647 & 100.02 & $\mathrm{E}$ \\
$($ Day-1 $)$ & NP2 & 0.19 & 4.58 & 0.5457 & 100.69 & $\mathrm{E}$ \\
& P1 & 0.205 & 6.72 & 0.2247 & 99.26 & $\mathrm{E}$ \\
& P2 & 0.202 & 6.66 & 0.1939 & 98.81 & $\mathrm{E}$ \\
\hline $15 / 04$ & NP1 & 0.58 & 0.79 & 1.0847 & 89.12 & $\mathrm{E}$ \\
$($ Day-22 $)$ & NP2 & 0.57 & 0.98 & 0.7532 & 89.05 & $\mathrm{E}$
\end{tabular}




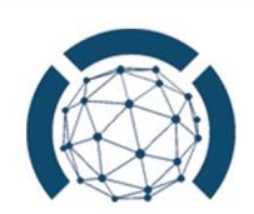

\begin{tabular}{cccccc}
\hline $\mathrm{P} 1$ & 0.58 & 1.53 & 0.1367 & 85.53 & $\mathrm{E}$ \\
P2 & 0.78 & 1.75 & 0.0151 & 77.55 & $\mathrm{E}$ \\
\hline Sample point $=N P$ - mesocosms with no FPV cover; P-mesocosms with no FPV cover &
\end{tabular}

$* *$ State $=$ E-Eutrophic

The transparency of the initial water of Mahoni Lake is very low. At the beginning (day-1), measured Secchi disc visibility of mesocosms without FPV cover were 0.192 and $0.19 \mathrm{~m}$, and the final measure at day-22 were 0.58 and $0.57 \mathrm{~m}$. The minimum measured Secchi disc visibility in mesocosms without FPV cover is $0.19 \mathrm{~m}$ and the maximum is $0.72 \mathrm{~m}$, the average is $0.56 \mathrm{~m}$. In mesocosms with $100 \%$ FPV cover, the initial Secchi disc visibility at day-1 were 0.205 and $0.202 \mathrm{~m}$, while the final measure at day-22 were 0.58 and $0.78 \mathrm{~m}$. The minimum measured Secchi disc visibility in mesocosms with $100 \%$ FPV cover is $0.202 \mathrm{~m}$ and the maximum is $0.8 \mathrm{~m}$, the average is $0.62 \mathrm{~m}$.

The initial chlorophyll-a concentrations of mesocosms without FPV cover at day-1 were 0.5647 and $0.5457 \mathrm{mg} / \mathrm{L}$, while the final concentrations at day-22 were 1.0847 and $0.7532 \mathrm{mg} / \mathrm{L}$. The minimum chlorophyll-a in mesocosms without FPV cover is $0.5138 \mathrm{mg} / \mathrm{L}$ and the largest is $1.3377 \mathrm{mg} / \mathrm{L}$, the average is $0.8328 \mathrm{mg} / \mathrm{L}$. In mesocosms with $100 \%$ FPV cover, the initial chlorophyll-a concentrations at day-1 were 0.2247 and $0.1939 \mathrm{mg} / \mathrm{L}$, while the final concentrations at day-22 were $0.1367 \mathrm{mg} / \mathrm{L}$ and a very low value of $0.0151 \mathrm{mg} / \mathrm{L}$. The minimum chlorophyll-a in mesocosms with $100 \% \mathrm{FPV}$ cover is $0,0151 \mathrm{mg} / \mathrm{L}$ and the largest is $0.2247 \mathrm{mg} / \mathrm{L}$, the average is $0,1128 \mathrm{mg} / \mathrm{L}$. Mesocosms with 100\% FPV cover showed a significant decrease of chlorophyll-a contents, while mesocosms without FPV cover showed increased chlorophyll-a contents instead. It was due to the cover effect, caused by algae's inability to photosynthesize that led to lower chlorophyll-a content (Li et al., 2011). According to the World Health Organization (WHO), the value of chlorophyll-a concentration in mesocosms with $100 \%$ FPV cover is close to the limit of chlorophyll-a concentration that is safe for a recreational water environment, which is $10 \mu \mathrm{g} / \mathrm{L}$ (World Health Organization, 2013). Low concentrations of these primary producers will be critical because these microalgae are an important part of the water bodies' food chain (Haas et al., 2020).

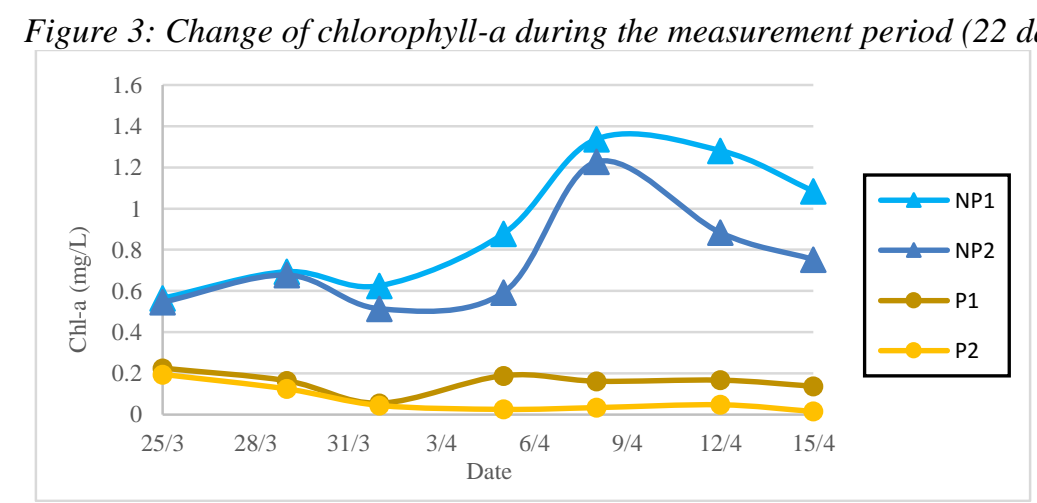

Our results show that chlorophyll-a of mesocosms with 100\% FPV cover were lower (p-value < 0.05) than chlorophyll-a of mesocosms without FPV cover (Figure 3). FPV 
may affect ecology because photosynthesis is controlled by light. In general, the physical cover effect can prevent photosynthesis by algae in water (Yeh et al., 2014). Overly extreme coverage may eliminate all pelagic primary producers, such as microalgae, which may have a negative effect on the entire food chain which potentially becomes a threat to the ecosystem (Haas et al., 2020).

The initial total phosphorus concentrations of mesocosms without FPV cover at day1 were 3.94 and $4.58 \mathrm{mg} / \mathrm{L}$, while the final concentrations day-22 were 0.79 and 0.98 $\mathrm{mg} / \mathrm{L}$. The minimum total phosphorus in mesocosms without FPV cover is $0.79 \mathrm{mg} / \mathrm{L}$ and the largest is $4.58 \mathrm{mg} / \mathrm{L}$, the average total phosphorus is $1.85 \mathrm{mg} / \mathrm{L}$. In mesocosms with $100 \%$ FPV cover, the initial total phosphorus concentrations at day-1 were 6.72 and $6.66 \mathrm{mg} / \mathrm{L}$, while the final concentrations at day-22 were 1.53 and $1.75 \mathrm{mg} / \mathrm{L}$. The minimum total phosphorus in mesocosms with $100 \%$ FPV cover is $1.53 \mathrm{mg} / \mathrm{L}$ and the largest is $6.72 \mathrm{mg} / \mathrm{L}$, the average total phosphorus is $2.71 \mathrm{mg} / \mathrm{L}$. All four mesocosms showed a significant decrease of total phosphorus concentrations. Due to the growth of algae, a significant decline of the total phosphorus content occurred (Yeh et al., 2014).

Figure 4: Change of total phosphorus during the measurement period (22 days)

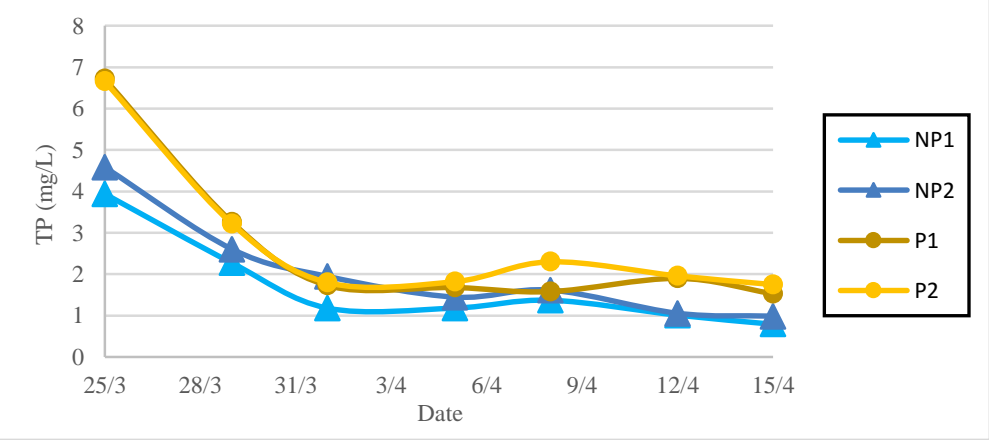

The mesocosms without FPV cover showed a slightly higher total phosphorus content compared to mesocosms with $100 \%$ FPV due to the growth of microalgae. As seen in Figure 4, total phosphorus concentrations of mesocosms with 100\% FPV cover were slightly higher ( $\mathrm{p}$-value > 0.05) than total phosphorus concentrations of mesocosms without FPV cover. The phenomena can be explained by how total phosphorus concentration was closely related to algae growth (Li et al., 2011). When light was hindered by FPV, disruption to algae growth occurred. This actively demonstrates that FPV cover could not effectively reduce total phosphorus concentration, due to the hindered light that disrupted algae growth which caused the total phosphorus concentrations to increase.

The advantage of TSI is that the relationship between variables can be used to identify certain conditions in water bodies that can limit algae growth (Ivankovic et al., 2018). The initial TSI values of mesocosms without FPV cover at day-1 were initially 100.02 and 100.69, and the final TSI values at day-22 were 89.12 and 89.05. The minimum TSI values in mesocosms without FPV cover is 88.7 and the largest is 100.69, the average is 92.02 . In mesocosms with $100 \%$ FPV cover, the initial TSI values at day1 were 99.26 and 98.81, and the final TSI values at day-22 were 85.53 and 77.54. The minimum TSI values in mesocosms with $100 \%$ FPV cover is 77.54 and the largest is 
99.26, the average is 86.06. The mesocosms without FPV cover showed a slightly higher TSI value compared to mesocosms with $100 \%$ FPV. According to the TSI value, from day-1 until day-22, all four mesocosms were classified as eutrophic.

From the graphic shown in Figure 5, it shows that mesocosms with 100\% FPV cover had lower TSI values ( $\mathrm{p}$-value < 0.05) compared to mesocosms without FPV cover. Despite the decrease in TSI value, the trophic state was still classified as eutrophic. It was caused by the high total phosphorus concentration which led to a higher TSI value (Yeh et al., 2014). High phosphorus content might be due to the accumulation of unused phosphorus that was reserved in water, both in forms of mineral and dead organic matter (Skwierawski, 2013). In addition, the availability of light in the water bodies strongly affects rates of primary production and algal community (Havens at al., 1998). The chlorophyll-a concentration in mesocosms with $100 \%$ FPV cover has a low value due to obstructed algae growth due to limit of light, resulting in a low TSI value.

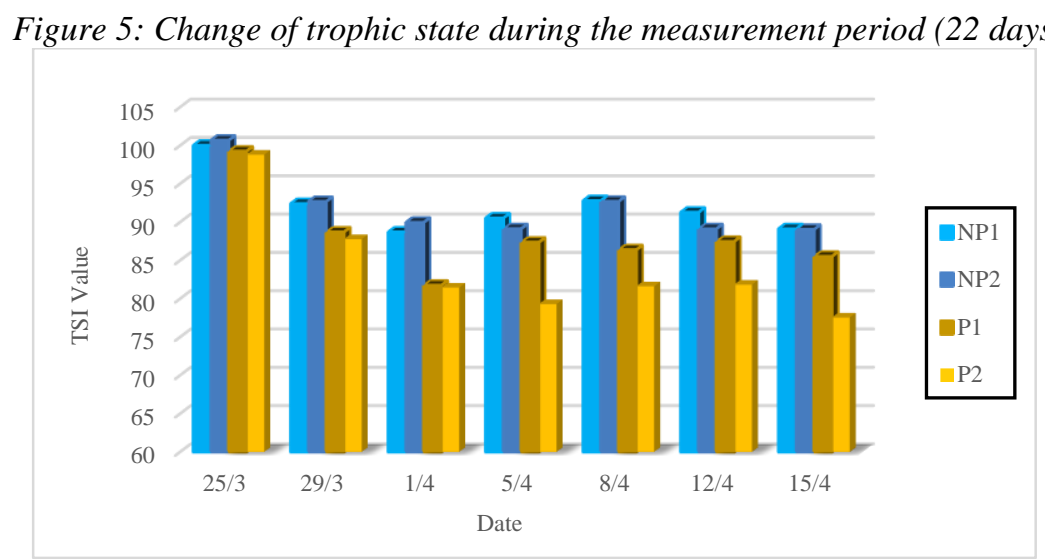

\section{Conclusion}

We present an experimental study regarding the effect of floating photovoltaic (FPV) on dissolved oxygen and trophic state changes using mesocosm experiment. As shown in the results, we can infer that mesocosms with $100 \%$ FPV cover (as P) have lower dissolved oxygen ( $\mathrm{p}$-value $<0,05)$ and TSI value ( $\mathrm{p}$-value $<0,05)$ compared to the mesocosms without FPV cover (as NP). According to the chlorophyll-a data, mesocosm without FPV cover increases algae growth, while mesocosms with $100 \%$ FPV cover decreases it. The results show controlling algae growth in water bodies can be done by blocking the light with a physical cover, which causes algae photosynthesis to be prevented.

Total phosphorus from mesocosms with $100 \%$ FPV cover has a slightly lower value compared to mesocosms without FPV cover. It is caused by how total phosphorus is closely related to algae growth. However, covering light with FPV cannot effectively reduce the nutrients in cover bodies. According to the TSI value, from day-1 to day-22, all four mesocosms are classified as eutrophic. The results obtained are an important tool for further studies focusing on water quality and ecology impact regarding FPV on water bodies. Every information obtained becomes a useful consideration for those who 
are engaged in renewable energy projects, addressing better management practices for a more sustainable future.

\section{Acknowledgment}

The authors would like to thank Universitas Indonesia, Universitas Indonesia Environmental Health and Engineering Laboratory (TPL UI), and Tropical Renewable Energy Center (TREC FT UI) for providing the facilities and resources to carry out this research.

\section{References}

Bekteshi, A., \& Cupi, A. (2014). Use of trophic state index (Carlson, 1977) for assessment of trophic status of the Shkodra lake. Journal of Environmental Protection and Ecology, 15(1), 359-365.

Carlson, R. E. (1997). A Trophic State Index for Lakes. Limnology and Oceanography, 22(March 1977), 361-369.

Chang, Y., Ku, C., \& Yeh, N. (2014). Solar powered artificial floating island for landscape ecology and water quality improvement. Ecological Engineering, 69(369), 8-16.

Château, P., Wunderlich, R. F., Wang, T., Lai, H., Chen, C., \& Chang, F. (2019). Mathematical modeling suggests high potential for the deployment of floating photovoltaic on fish ponds. Science of the Total Environment, 687, 654-666.

Escaravage, V., Peperzak, L., Prins, T. C., Peeters, J. C. H., \& Joordens, J. C. A. (1995). The development of a phaeocystis bloom in a mesocosm experiment in relation to nutrients, irradiance and coexisting algae. Ophelia, 42(1), 55-74.

Gillette, J. P., Schulz, K. L., \& Teece, M. A. (2014). Light Apparatus for Mesocosm Photo-manipulation (LAMP): An inexpensive waterproof lighting device for within-lake mesocosm experiments. Limnology and Oceanography: Methods, 12(AUG), 592-603.

Haas, J., Khalighi, J., Fuente, A. De, Gerbersdorf, S. U., Nowak, W., \& Chen, P. (2020). Floating photovoltaic plants: Ecological impacts versus hydropower operation flexibility. Energy Conversion and Management, 206(September 2019).

Havens, K. E., Phlips, E. J., Cichra, M. F., \& Li, B. L. (1998). Light availability as a possible regulator of cyanobacteria species composition in a shallow subtropical lake. Freshwater Biology, 39(3), 547-556.

Ivankovic, A., Cosic, N., Knezovic, Z., \& Vasilj, V. (2018). Trophic status of blidinje lake (Bosnia and Herzegovina) based on the determination of the Trophic State Index (TSI). Ekologia Bratislava, 37(1), 1-10.

Landkildehus, F., Søndergaard, M., Beklioglu, M., Adrian, R., Angeler, D. G., Hejzlar, J., Papastergiadou, E., Zingel, P., Çakiroğlu, A. I., Scharfenberger, U., Drakare, S., Nõges, T., Šorf, M., Stefanidis, K., Nihan Tavşanoğlu, Ü., Trigal, C., Mahdy, A., Papadaki, C., Tuvikenek, L., ... Jeppesen, E. (2014). Climate change effects 
on shallow lakes: Design and preliminary results of a cross-European climate gradient mesocosm experiment. Estonian Journal of Ecology, 63(2), 71-89.

Li, W., Guo, Y., \& Fu, K. (2011). Enclosure experiment for influence on algae growth by shading light. Procedia Environmental Sciences, 10(PART B), 1823-1828.

Machado, L. F., de Assis Leite, D. C., da Costa Rachid, C. T. C., Paes, J. E., Martins, E. F., Peixoto, R. S., \& Rosado, A. S. (2019). Tracking Mangrove Oil Bioremediation Approaches and Bacterial Diversity at Different Depths in an in situ Mesocosms System. Frontiers in Microbiology, 10(September), 1-14.

Nürnberg, G. K. (1996). Trophic state of clear and colored, soft- and hardwater lakes with special consideration of nutrients, anoxia, phytoplankton and fish. Lake and Reservoir Management, 12(4), 432-447.

Prasad, A. G. D., \& Siddaraju. (2012). Carlson's Trophic State Index for the assessment of trophic status of two Lakes in Mandya district. Pelagia Research Library, 3(5), 2992-2996.

Qiu, N., Wang, X., \& Zhou, F. (2017). A new method for fast extraction and determination of chlorophylls in natural water. Zeitschrift für Naturforschung $C$, 73(1-2), 1-10.

Sahu, A., Yadav, N., \& Sudhakar, K. (2016). Floating photovoltaic power plant: A review. Renewable and Sustainable Energy Reviews, 66, 815-824.

Santafé, M. R., Soler, J. B. T., Romero, F. J. S., Gisbert, P. S. F., Gozálvez, J. J. F., \& Gisbert, C. M. F. (2014). Theoretical and experimental analysis of a floating photovoltaic cover for water irrigation reservoirs. Energy, 67, 246-255.

Skwierawski, A. (2013). The use of the Integrated Trophic State Index in evaluation of the restored shallow water bodies. ECOL CHEM ENG A, 20(November 2013), $1275-1283$.

Sommer, U., Aberle, N., Engel, A., Hansen, T., Lengfellner, K., Sandow, M., Wohlers, J., Zöllner, E., \& Riebesell, U. (2007). An indoor mesocosm system to study the effect of climate change on the late winter and spring succession of Baltic Sea phyto- and zooplankton. Oecologia, 150(4), 655-667.

Stewart, R. I. A., Dossena, M., Bohan, D. A., Jeppesen, E., Kordas, R. L., Ledger, M. E., Meerhoff, M., Moss, B., Mulder, C., Shurin, J. B., Suttle, B., Thompson, R., Trimmer, M., \& Woodward, G. (2013). Mesocosm Experiments as a Tool for Ecological Climate-Change Research. In Advances in Ecological Research (1 ed., Vol. 48). Elsevier Ltd.

Tonetta, D., Anton, P., Obrador, B., Pena, L., Brandão, M., Silva, L., Mello, M., Antônio, F., \& Barbosa, R. (2018). Effects of nutrients and organic matter inputs in the gases $\mathrm{CO} 2$ and $\mathrm{O} 2$ : A mesocosm study in a tropical lake. Limnologica, 69(February), 1-9.

Winder, M., Berger, S. A., Lewandowska, A., Aberle, N., Lengfellner, K., Sommer, U., \& Diehl, S. (2012). Spring phenological responses of marine and freshwater 


\section{$7^{\text {th }}$ International Conference On}

\section{Modern Approaches in SCIENCE,}

TECHNOLOGY \& ENGINEERING

18-20 June, 2021

Brussels, Belgium

plankton to changing temperature and light conditions. Marine Biology, 159(11), 2491-2501.

World Health Organization. (2013). Guidelines for safe recreational water environments. Volume 1, Coastal and fresh waters. (Vol. 1).

Yeh, T., Wu, M., Cheng, C., \& Hsu, Y. (2014). A Study and Analysis on the Physical Shading Effect of Water Quality Control in Constructed Wetlands. Journal of Civil \& Environmental Engineering, 4(3).

Zingel, P., Cremona, F., Nõges, T., Cao, Y., Neif, É. M., Coppens, J., Işkın, U., Lauridsen, T. L., Davidson, T. A., Søndergaard, M., Beklioglu, M., \& Jeppesen, E. (2018). Effects of warming and nutrients on the microbial food web in shallow lake mesocosms. European Journal of Protistology, 64, 1-12. 